\title{
Pengaruh Model CORE dengan Pendekatan Open Ended terhadap Kemampuan Pemecahan Masalah Matematis Siswa SMP
}

\author{
Putri Safrina Wahyuningtyas ${ }^{1 *}$, Yani Setiani ${ }^{2}$, Etika Khaerunnisa ${ }^{3}$ \\ ${ }^{1,2,3}$ Universitas Sultan Ageng Tirtayasa \\ *putrisaf1996@gmail.com
}

Diterima: Oktober 2019. Disetujui: Desember 2019. Dipublikasikan: Januari 2020.

\begin{abstract}
ABSTRAK
Penelitian ini dilatarbelakangi oleh rendahnya kemampuan pemecahan masalah matematis siswa SMP sehingga dibutuhkan model pembelajaran yang dapat meningkatkan kemampuan tersebut. Model pembelajaran CORE dengan pendekatan open ended diyakini mampu meningkatkan kemampuan pemecahan masalah matematis pada siswa SMP. Penelitian ini dilaksanakan di SMP Negeri 8 Kota Serang tahun ajaran 2018/2019 yang bertujuan untuk melihat pengaruh model CORE dengan pendekatan open ended terhadap kemampuan pemecahan masalah matematis siswa SMP. Metode penelitian yang digunakan dalam penelitian ini adalah kuasi eksperimen dengan desain the nonequivalen pretest posttest control group design. Penelitian ini melibatkan dua kelas yang terdiri dari kelas eksperimen dan kelas kontrol. Populasi dalam penelitian ini adalah seluruh siswa kelas VII SMP Negeri 8 Kota Serang. Sampel penelitian ini adalah kelas VII A sebagai kelas eksperimen dan kelas VII B sebagai kelas kontrol. Instrumen yang digunakan dalam penelitian ini berupa instrumen tes kemampuan pemecahan masalah matematis. Hasil penelitian memberikan kesimpulan bahwa pencapaian dan peningkatan kemampuan pemecahan masalah matematis siswa dengan menggunakan model pembelajaran CORE dengan pendekatan open ended lebih baik daripada pencapaian dan peningkatan kemampuan pemecahan masalah matematis siswa dengan menggunakan pembelajaran ekspositori.

Kata kunci: Model CORE, pendekatan Open Ended, kemampuan pemecahan masalah matematis.
\end{abstract}

\begin{abstract}
This research is motivated by the low ability of problem solving skills of junior high school students. So that a learning model needed that can enhance this ability. The CORE model with open ended approach is believed to be able to improve problem solving skills in junior high school students. The research was conducted in Junior High School 8 Serang 2018/2019 academic year which aim to see the influence of CORE model with open ended approach on problem solving skills of junior high school students. The research method used in this study is quasi-experimental with the type of design that is the nonequivalent pretest posttest control group design. This studi involved two classes consisting of the experimental class and the control class. The population in this study were all students of class grade VII of Junior High School 8 Serang. The sample of this tudy was the VII A class as experimental class and VII B class as control class. The instrumen used in this study was a mathematical problem solving test instrument. The results of the study concluded that the achievement and improvement of students' mathematical problem solving abilities using the CORE learning model with an open ended approach was better than the achievement and improvement of students' mathematical problem solving abilities by using expository learning.
\end{abstract}

Keywords: CORE Model, Open Ended approach, problem solving.

How to Cite: Wahyuningtyas, P. S., Setiani, Y., \& Kherunnisa, E. (2020). Model CORE dengan Pendekatan Open Ended terhadap Kemampuan Pemecahan Masalah Matematis Siswa SMP. Journal of Medives: Journal of Mathematics Education IKIP Veteran Semarang, 4(1), 81-96. 


\section{PENDAHULUAN}

Peningkatan kualitas sumber daya manusia sangat diperlukan selaras dengan perkembangan ilmu pengetahuan dan teknologi. Upaya yang dapat menentukan kualitas sumber daya manusia adalah pendidikan. Tugas berat pendidikan adalah menciptakan sumber daya manusia yang berkualitas sehingga mampu hidup dalam lingkungan yang selalu dinamis dan penuh kompetisi sehingga setiap individu perlu menempuh pendidikan. Salah satu proses dalam pendidikan adalah pembelajaran.

Pelaksanaan pembelajaran menghasilkan pencapaian dalam bentuk perubahan perilaku yang cenderung menetap yang disebut hasil belajar (Jihad \& Haris, 2012: 14). Bloom dalam Sudjana (2010: 22) menyatakan bahwa secara garis besar hasil belajar dibagi menjadi tiga ranah yaitu ranah kognitif, ranah afektif, dan ranah psikomotor. Ranah kognitif berkenaan dengan kemampuan berpikir, kompetensi memperoleh pengetahuan, pengenalan, pemahaman, konseptualisasi, penentuan, dan penalaran. Ranah afektif berkenaan dengan sikap, nilai, perasaan, emosi, serta derajat penerimaan atau penolakan suatu objek dalam kegiatan belajar mengajar. Ranah psikomotor meliputi kompetensi yang berkaitan dengan gerak fisik yang terdiri dari gerakan refleks, keterampilan gerakan dasar, kemampuan perseptual, ketepatan, keterampilan kompleks serta ekspresif, dan interpretatif (Suryana, 2016: 12).

Tiga aspek yang telah dipaparkan sebelumnya, dapat dikembangkan melalui pembelajaran matematika. Hal ini sesuai dengan tujuan mata pelajaran matematika dalam Permendiknas Nomor 22 Tahun 2006 yang menyatakan bahwa tujuan pembelajaran matematika yaitu agar siswa memiliki kemampuan 1) memahami konsep matematika, menjelaskan keterkaitan antar konsep dan mengaplikasikan konsep dalam pemecahan masalah, 2) menggunakan penalaran dalam membuat generalisasi dan menjelaskan gagasan matematika, 3) memecahkan masalah yang meliputi kemampuan memahami masalah, merancang model matematika, menyelesaikan model, serta menafsirkan solusi yang diperoleh, 4) mengomunikasikan gagasan matematis dengan simbol, tabel, diagram, atau media lain untuk memperjelas keadaan atau masalah, 5) memiliki sikap menghargai matematika dalam kehidupan yaitu memiliki rasa ingin tahu, perhatian, dan minat dalam kehidupan serta sikap ulet dan percaya diri dalam pemecahan masalah.

Sejalan dengan tujuan mata pelajaran matematika tersebut, National Council of Teacher Mathematics (NCTM) (2000: 4) menetapkan lima standar proses yang harus dikuasai oleh siswa dalam pembelajaran matematika yaitu kemampuan pemecahan masalah, kemampuan komunikasi, kemampuan koneksi, kemampuan penalaran, dan kemampuan representasi. Berdasarkan hal tersebut maka salah satu fokus utama dalam pembelajaran matematika adalah kemampuan pemecahan masalah matematis.

Pemecahan masalah merupakan upaya yang dilakukan untuk menyelesaikan suatu permasalahan. Pemecahan masalah matematis merupakan kegiatan yang dilakukan dengan melibatkan 
pemikiran tingkat tinggi yang berasal dari pengetahuan lain untuk menerima dan menyelesaikan masalah (Husniah dkk, 2017: 841). Vitasari \& Trisniawati (2017: 79) menyatakan bahwa individu yang memiliki kemampuan pemecahan masalah yang baik dapat menemukan cara yang tepat sebagai solusi untuk menyelesaikan masalah yang dihadapinya. Jadi dalam melakukan pemecahan masalah siswa harus mengetahui dan memahami serta menggunakan prosedur dan strategi yang tepat. Menurut Kusumah (2010) pemecahan masalah sebagai suatu tujuan memuat tiga kemampuan yang ingin dicapai, yakni memodelkan masalah sehari-hari dengan memakai simbol dan notasi matematik, menerapkan strategi untuk menyelesaikan berbagai masalah (masalah sejenis ataupun masalah baru) di dalam atau di luar matematika serta menafsirkan hasil yang diperoleh secara bermakna dengan konteks masalah

Proses dan strategi yang dilakukan siswa dalam pemecahan masalah merupakan hal yang lebih diutamakan dari pada sekedar hasilnya. Menurut Polya dalam (Noriza \& Kartono, 2015: 348) terdapat empat fase pada proses pemecahan masalah matematis yaitu memahami masalah, merencanakan pemecahan masalah, melakukan pemecahan masalah dan pengecekkan kembali hasil pemecahan masalah. Pada kenyataannya, kemampuan pemecahan masalah siswa Indonesia masih tergolong rendah. Hal ini ditunjukkan oleh hasil survei yang dilakukan oleh Trends in Mathematics and Science Study (TIMSS) pada tahun 2015 (Utami \& Wutsqa, 2017: 167) di mana Indonesia berada pada peringkat 45 dari 50 negara peserta dengan skor rata-rata 397. Berdasarkan data hasil survei TIMSS tersebut mengenai literasi matematika yang di dalamnya memuat indikatorindikator pemecahan masalah menunjukkan bahwa kemampuan siswa di Indonesia dalam menyelesaikan soalsoal berstandar Internasional masih rendah terutama kemampuan pemecahan masalah matematis. Utami \& Wutsqa (2017: 172) menyatakan bahwa rendahnya kemampuan pemecahan masalah matematis disebabkan oleh siswa yang kurang memahami informasi pada soal, siswa kurang mampu membuat model matematis, dan siswa kurang teliti dalam menyelesaikan soal. Sedangkan Murni (2013: 2) menyatakan bahwa rendahnya kemampuan matematis siswa karena siswa belum terbiasa dalam menyelesaikan soal non rutin yang menantang untuk berpikir. Oleh karena itu, pengembangan kemampuan pemecahan masalah matematis siswa perlu diperhatikan.

Pengembangan kemampuan pemecahan masalah matematis siswa dapat dilakukan dengan menerapkan model pembelajaran yang memfasilitasi kemampuan tersebut. Model pembelajaran yang dimaksud adalah model pembelajaran yang memungkinkan siswa untuk mengonstruk pengetahuannya sendiri sehingga pembelajaran menjadi bermakna. Salah satu model pembelajaran yang dapat dipertimbangkan untuk mengembangkan kemampuan pemecahan masalah matematis siswa adalah model CORE. Calfee et al. dalam Jacob (2005: 13) menyatakan bahwa model CORE merupakan model 
pembelajaran dengan menggunakan metode diskusi dengan melibatkan siswa secara aktif dalam perkembangan pengetahuannya. Menurut Lestari \& Yudhanegara (2015: 53) model CORE merupakan model pembelajaran konstruktivisme yang meliputi empat tahap yaitu connecting (mengoneksikan informasi lama dengan informasi baru dan antar konsep), organizing (mengorganisasi ide untuk memahami materi dan memecahkan permasalahan), reflecting (memikirkan kembali, mendalami, dan menggali), dan extending (menemukan, mengembangkan, memperluas, dan menggunakan).

Salah satu kelebihan model CORE adalah mengembangkan kemam-puan pemecahan masalah (Shoimin, 2014: 40). Hal ini sejalan dengan penelitian Satriani dkk (2015) yang menyatakan bahwa model CORE mem-berikan keleluasaan yang optimal bagi siswa untuk melatih dan mengembang-kan kemampuan pemecahan masalah yang berpengaruh langsung terhadap pemecahan masalah matematika siswa. Proses pembelajaran model CORE akan dipadukan dengan pendekatan open ended. Pendekatan open ended merupakan pendekatan pembelajaran yang juga dilandasi dengan kosntruktivisme. Lestari dan Yudhanegara (2015: 42) menjelaskan bahwa pembelajaran open ended dimulai dengan fase open ended problem yaitu pemberian masalah terbuka pada siswa. Kedua, fase constructivism yaitu siswa menemukan pola untuk mengonstruksi permasalahannya sendiri. Ketiga, fase exploration yaitu siswa menyelesaikan masalah dengan banyak cara penyelesaian melalui kegiatan eksplorasi. Dan keempat, fase presentation yaitu siswa menyajikan hasil temuannya. Masalah open ended menuntuntut siswa untuk dapat menyelesaikan masalah secara mudah dan fleksibel. Konstruk dalam menyelesaikan masalah diperoleh melalui diskusi yang difasilitasi oleh model CORE. Dalam diskusi, siswa dapat saling bertukar informasi dan bekerjasama sehingga memungkinkan munculnya gagasan baru yang berakhir pada penemuan cara baru sebagai solusi permasalahan.

Berdasarkan latar belakang tersebut peneliti, adapun rumusan masalah dalam penelitian ini adalah apakah pencapaian dan peningkatan kemampuan pemecahan masalah matematis siswa yang menggunakan model pembelajaran CORE dengan pendekatan open ended lebih baik daripada pencapaian dan peningkatan kemampuan pemecahan masalah matematis siswa dengan menggunakan pembelajaran ekspositori?

\section{METODE PENELITIAN}

Penelitian dilakukan di SMP Negeri 8 Kota Serang dengan populasi seluruh siswa kelas VII tahun ajaran 2018/2019. Sampel dalam penelitian ini diambil melalui teknik purposive sampling, yakni sampel diambil dengan pertimbangan tertentu (Sugiyono, 2012: 85). Teknik purposive sampling dipilih karena terdapat pertimbangan tertentu dalam pemilihan sampel antara lain sampel dalam sekolah memiliki tingkat kelas yang sebanding, diampu oleh guru yang sama, serta materi pembelajaran yang sama. Dua kelas yang dipilih yaitu 
kelas VII A sebagai kelas eksperimen yang akan mendapatkan pembelajaran model CORE dengan pendekatan open ended dan kelas VII B sebagai kelas kontrol yang akan mendapatkan pembelajaran saintifik.

Metode dalam penelitian ini adalah kuasi eksperimen. Untuk mengetahui kemampuan pemecahan masalah matematis siswa antara sebelum dan sesudah pembelajaran dilakukan, maka dilakukan tes awal (pretest) dan tes akhir (posttest). Adapun desain penelitian yang digunakan adalah the nonequivalen pretest posttest Control Group Design (Sugiyono, 2012: 118).

Instrumen yang digunakan dalam penelitian adalah instrumen tes kemampuan pemecahan masalah matematis berupa soal uraian yang disesuaikan dengan indikator kemampuan pemecahan masalah matematis. Untuk mengukur keabsahan instrumen tes yang dibuat, instrumen diujicobakan terlebih dahulu dengan menghitung validitas, reliabilitas, daya pembeda dan indeks kesukaran.

Teknik analisis data dilakukan dengan pengolahan data yang diperoleh dengan menggunakan rumus-rumus atau aturan-aturan yang ada sesuai dengan pendekatan penelitian atau desain penelitian yang digunakan. Langkahlangkah yang digunakan dalam analisis data pada penelitian ini adalah uji normalitas, uji homogenitas, uji beda dua rata-rata, dan uji $\mathrm{N}$-gain.

\section{HASIL DAN PEMBAHASAN}

Pengukuran kemampuan pemecahan masalah matematis dilakukan sesudah pemberian perlakuan terhadap kelas eksperimen maupun kelas kontrol.
Adapun analisis statistika deskritif disajikan pada Tabel 1.

Tabel 1. Statistika Deskriptif Kemampuan Pemecahan Masalah Matematis

\begin{tabular}{cllll}
\hline \multirow{2}{*}{ Data } & \multicolumn{2}{c}{ Eksperimen } & \multicolumn{2}{c}{ Kontrol } \\
& Posttest & N-gain & Posttest & N-gain \\
\hline $\mathrm{N}$ & 25 & & & \\
$\bar{x}$ & 9,16 & 0,32 & 6,60 & 0,00 \\
$\mathrm{~S}$ & 3,16 & 0,29 & 2,92 & 0,27 \\
SMI & 16 & & & \\
\hline
\end{tabular}

Berdasarkan Tabel 1, dapat dilihat bahwa data posttest kemampuan pemecahan masalah matematis diambil dari kelas eksperimen dan kelas kontrol yang masing-masing siswanya berjumlah 25 siswa. Kemudian dapat dilihat bahwa nilai rata-rata posttest kelas eksperimen 9,16 dan nilai rata-rata kelas kontrol 6,60 dengan selisih 2,56. Selain itu, simpangan baku posttest kelas eksperimen 3,16 dan kelas kontrol 2,92. Hal ini menunjukkan bahwa data posttest kelas eksperimen lebih beragam dibandingkan dengan kelas kontrol. Berdasarkan data tersebut, secara deskriptif nampak bahwa terdapat perbedaan pada pencapaian akhir kemampuan pemecahan masalah siswa dimana hasil pencapaian akhir kelas eksperimen lebih tinggi daripada kelas kontrol. Selanjutnya, dari Tabel 1 diketahui bahwa data N-gain kemampuan pemecahan masalah diambil dari kelas eksperimen dan kelas kontrol yang masing-masing siswanya berjumlah 25 siswa. Kemudian dapat dilihat bahwa rata-rata $\mathrm{N}$-gain kelas eksperimen 0,32 dan kelas kontrol 0,00. Selain itu, simpangan baku N-gain kelas eksperimen 0,29 dan kelas kontrol 0,27. Hal tersebut menunjukkan bahwa data 
Tabel 2. Hasil Uji Normalitas Posttest Kemampuan Pemecahan Masalah Matematis

\begin{tabular}{lccc}
\hline \multicolumn{1}{c}{ Kelas } & D-hitung & D-tabel & Keputusan \\
\hline Eksperimen & 0,15 & 0,26 & $H_{0}$ diterima \\
Kontrol & 0,14 & 0,26 & $H_{0}$ diterima
\end{tabular}

Tabel 3. Hasil Uji Homogenitas Posttest Kemampuan Pemecahan Masalah Matematis

\begin{tabular}{lccccc}
\hline \multicolumn{1}{c}{ Kelas } & Varians & Dk & F-hitung & F-tabel & Keputusan \\
\hline Eksperimen & 9,97 & 24 & \multirow{2}{*}{1,17} & \multirow{2}{*}{1,98} & $H_{0}$ diterima \\
Kontrol & 8,50 & 24 & & & \\
\hline
\end{tabular}

Tabel 4. Uji t Kemampuan Pemecahan Masalah Matematis

\begin{tabular}{llll}
\hline t-hitung & t-tabel & Dk & Kesimpulan \\
\hline 2,98 & 2,01 & 48 & $H_{0}$ diterima \\
\hline
\end{tabular}

kelas eksperimen lebih beragam daripada kelas kontrol. Berdasarkan data tersebut, secara deskriptif nampak bahwa walaupun terdapat peningkatan kemam-puan pemecahan masalah pada kelas kontrol namun peningkatan tersebut tidak sebesar peningkata pada kelas eksperimen.

\section{Pencapaian Kemampuan Pemecahan Masalah Matematis}

Data yang digunakan untuk mengetahui pencapaian kemampuan pemecahan masalah matematis adalah data posttest. Untuk menentukan uji statistik yang akan digunakan, terlebih dahulu dilakukan uji prasyarat yaitu uji normalitas dan uji homogenitas. Uraian uji prasyarat statistik sebagai berikut.

\section{Uji Normalitas}

Berdasarkan Tabel 2 diketahui bahwa skor D-hitung posttest kelas eksperimen lebih kecil dari D-tabel yaitu $0,15<0,26$ sehingga dapat dinyatakan bahwa $H_{0}$ diterima. Sehingga disimpulkan bahwa data posttest kelas eksperimen berasal dari populasi yang berdistribusi normal. Pada kelas kontrol diperoleh bahwa skor D-hitung posttest kelas eksperimen lebih kecil dari D-tabel yaitu $0,14<0,26$ sehingga dapat dinyatakan bahwa $H_{0}$ diterima. Sehingga disimpulkan bahwa data posttest kelas kontrol berasal dari populasi yang berdistribusi normal.

\section{Uji Homogenitas}

Berdasarkan hasil perhitungan uji homogenitas pada Tabel 3 diperoleh skor F-hitung $=1,17$ dan F-tabel $=1,98$ dengan taraf signifikan 0,05 . Setelah dibandingkan diperoleh bahwa F-hitung $<$ F-tabel maka $H_{0}$ diterima sehingga dapat disimpulkan bahwa kedua data homogen.

\section{Uji $t$}

Berdasarkan perhitungan diperoleh $\mathrm{t}$-hitung $=2,98$ dan skor $\mathrm{t}$-tabel $=$ 2,01 dengan $\mathrm{dk}=\mathrm{n}_{1}+\mathrm{n}_{2}-2=25+25-$ $2=48$. Skor t-hitung berada di daerah penolakan $H_{0}$ yaitu $2,98>2,01$ berdasarkan kriteria pengujian maka $H_{1}$ diterima pada taraf signifikan 0,05 sehingga dapat disimpulkan bahwa terdapat perbedaan antara pencapaian kemampuan pemecahan masalah matematis pada siswa kelas eksperimen dengan pencapaian kemampuan peme- 
Tabel 5. Hasil Uji Normalitas N-gain Kemampuan Pemecahan Masalah Matematis

\begin{tabular}{lccc}
\hline \multicolumn{1}{c}{ Kelas } & D-hitung & D-tabel & Keputusan \\
\hline Eksperimen & 0,20 & 0,26 & $H_{0}$ diterima \\
Kontrol & 0,22 & 0,26 & $H_{0}$ diterima \\
\hline
\end{tabular}

Tabel 6. Hasil Uji Homogenitas N-gain Kemampuan Pemecahan Masalah

\begin{tabular}{lccccc}
\hline \multicolumn{1}{c}{ Kelas } & Varians & Dk & F-hitung & F-tabel & Keputusan \\
\hline Eksperimen & 9,97 & 24 & \multirow{2}{*}{1,17} & 1,98 & $H_{0}$ diterima \\
Kontrol & 8,50 & 24 & & & \\
\hline
\end{tabular}

Tabel 7. Uji t Kemampuan Pemecahan Masalah Matematis

\begin{tabular}{cccc}
\hline t-hitung & t-tabel & Dk & Kesimpulan \\
\hline 4,13 & 2,01 & 48 & $H_{0}$ diterima \\
\hline
\end{tabular}

cahan masalah matematis pada siswa kelas kontrol.

Selanjutnya, berdasarkan perhitungan uji $\mathrm{t}$ diperoleh $\mathrm{H}_{1}$ diterima maka $\mu_{l}>\mu_{2}$ dengan demikian dapat disimpulkan bahwa pencapaian kemampuan pemecahan masalah matematis siswa yang mendapatkan model CORE dengan pendekatan open ended lebih baik daripada siswa yang mendapatkan model saintifik.

\section{Peningkatkan Kemampuan Pemecah- an Masalah Matematis}

Data yang digunakan untuk melihat peningkatan kemampuan pemecahan masalah matematis adalah data $\mathrm{N}$ gain. Untuk menentukan uji statistik yang akan digunakan, terlebih dahulu dilakukan uji prasyarat yaitu uji normalitas dan uji homogenitas. Uraian uji prasyarat statistik sebagai berikut.

\section{Uji Normalitas}

Berdasarkan Tabel 5 diketahui bahwa Dhitung N-gain kelas eksperimen lebih kecil dari D-tabel yaitu $0,20<0,26$ sehingga dapat dinyatakan bahwa $H_{0}$ diterima. Sehingga disimpulkan bahwa data N-gain kelas eksperimen berasal dari populasi yang berdistribusi normal. Pada kelas kontrol diperoleh bahwa skor D-hitung N-gain kelas kontrol lebih kecil dari D-tabel yaitu $0,22<0,26$ sehingga dapat dinyatakan bahwa $H_{0}$ diterima. Sehingga disimpulkan bahwa data Ngain kelas kontrol berasal dari populasi yang berdistribusi normal.

\section{Uji Homogenitas}

Berdasarkan hasil perhitungan uji homogenitas pada Tabel 6 diperoleh skor F-hitung $=1,17$ dan F-tabel $=1,98$ dengan taraf signifikan 0,05 . Setelah dibandingkan diperoleh bahwa F-hitung $<$ F-tabel maka $H_{0}$ diterima sehingga dapat disimpulkan bahwa kedua data homogen.

\section{Uji $t$}

Berdasarkan perhitungan diperoleh thitung $=4,13$ dan skor t-tabel $=2,01$ dengan $\mathrm{dk}=\mathrm{n}_{1}+\mathrm{n}_{2}-2=25+25-2=$ 48. Skor t-hitung berada di daerah penolakan $H_{0}$ yaitu $4,13>2,01$ berdasarkan kriteria pengujian maka $H_{1}$ diterima pada taraf signifikan 0,05 sehingga dapat dinyatakan bahwa terdapat perbedaan peningkatan kemampuan pemecahan masalah matematis 
kelas eksperimen dengan peningkatan kemampuan pemecahan masalah matematis kelas kontrol.

Selanjutnya berdasarkan perhitungan uji $\mathrm{t}$ diperoleh $\mathrm{H}_{1}$ diterima maka $\mu_{1}>\mu_{2}$ dengan demikian dapat disimpulkan bahwa peningkatan kemampuan pemecahan masalah siswa yang mendapatkan model CORE dengan pendekatan open ended lebih baik daripada siswa yang mendapatkan model saintifik.

Berdasarkan pengujian hipotesis yang telah dilakukan, hasilnya menunjukkan bahwa pencapaian kemampuan pemecahan masalah matematis siswa kelas eksperimen yaitu siswa yang mendapatkan model CORE dengan pendekatan open ended lebih baik daripada siswa kelas kontrol yaitu siswa yang mendapatkan model saintifik. Hal ini dapat dilihat dari hasil perhitungan terhadap nilai posttest kemampuan pemecahan masalah matematis siswa pada kelas eksperimen dan kelas kontrol yang sebelumnya tidak memiliki perbedaan pada kemampuan awal. Hal ini menunjukkn bahwa model CORE dengan pendekatan open ended lebih memberikan pengaruh positif dalam pembelajaran matematika dalam pencapaian kemampuan pemecahan masalah matematis dibandingkan dengan model saintifik. Hal ini sejalan dengan penelitian Saputra (2016) bahwa model CORE dengan pendekatan scientific memberikan pengaruh positif terhadap kemampuan pemecahan masalah. Maftukhah (2017) menjelaskan bahwa siswa dengan kemampuan berpikir kreatif yang baik dapat memberikan banyak jawaban dari satu permasalahan yang diberikan.
Pembelajaran CORE dengan pendekatan open ended memberikan keleluasaan kepada siswa untuk mengeksplorasi pengetahuannya. Model CORE berperan sebagai alur yang menjembatani siswa untuk mampu mengeksplor kreativitasnya dalam mengatasi masalah yang dihadapi. Hal ini sejalan dengan hasil penelitian yang dilakukan oleh Arifah dkk (2016) manyatakan bahwa model CORE berbantuan studi kasus menuntut kreativitas siswa dalam memberikan solusi permasalahan yang diberikan secara mudah dan fleksibel. Adapun faktor yang memberikan pengaruh terhadap pencapaian kemampuan pemecahan masalah matematis dengan menerapkan model pembelajaran CORE dengan pendekatan open ended adalah pemberian soal yang bersifat open ended. Pemberian latihan-latihan soal yang bersifat open ended membuat siswa terbiasa melakukan pemecahan masalah yang bersifat open ended. Hal ini didukung oleh penelitian Murni (2013) yang menyatakan bahwa pembiasaan pemberian soal non rutin memberikan pengaruh terhadap kemampuan pemecahan masalah siswa. Pemberian masalah mengarahkan siswa untuk mengenal permasalahan dan memberikan solusi sebagai penyelesaian masalah. Masalah yang bersifat open ended memberikan tantangan kepada siswa untuk memberikan solusi yang efektif. Hal ini dikuatkan dalam penelitian Vitasari \& Trisniawati (2017: 79) individu yang memiliki kemampuan pemecahan masalah yang baik dapat menentukan cara yang tepat sebagai solusi untuk menyelesaikan masalah 
yang dihadapinya. Menyelesaikan masalah berarti menemukan cara yang tepat untuk sampai pada tujuan yang diinginkan. Siswa yang akan menyelesaikan masalah memerlukan pengetahuan sebelumnya yang dapat digunakan pada situasi baru misalnya dalam pemecahan masalah tersebut. Dalam pembelajaran menggunakan model CORE dengan pendekatan open ended siswa distimulasi untuk mengingat kembali pengetahuan sebelumnya yang didukung dengan pemberian pertanyaan-pertanyaan atau memberikan gambaran atau arahan yang berakitan dengan materi pembelajaran. Misalnya, ketika siswa akan menentukan keliling persegi panjang maka siswa diberikan gambaran yaitu ada seorang atlet berlari mengelilingi suatu lapangan yang berbentuk persegi panjang. Kemudian siswa diarahkan untuk menghitung jarak tempuh atlet tersebut jika mengelilingi lapangan persegi panjang sebanyak satu kali dan diarahkan bahwa hal tersebut merupakan cara untuk menentukan keliling persegi panjang. Tahap tersebut yang difasilitasi oleh tahap connecting. Hal ini didukung oleh penelitian yang dilakukan oleh Wardhani (2010: 15) bahwa pemecahan masalah adalah proses menerapkan pengetahuan yang telah diperoleh sebelumnya ke dalam situasi baru yang belum dikenal. Jadi kemampuan pemecahan masalah adalah kemampuan individu dalam menggunakan pengetahuannya untuk diterapkan ke dalam situasi baru sehingga tahap connecting merupakan salah satu faktor yang berkaitan dengan pemecahan masalah.

Faktor lain yang memberikan pengaruh positif terhadap pencapaian kemampuan pemecahan masalah matematis siswa yang menggunakan model CORE dengan pendekatan open ended adalah tahap organizing yaitu siswa saling bertukar dan mengumpulkan informasi atau pengetahuan dalam kegiatan diskusi yang akan digunakan untuk menyelesaikan masalah. Tahap diskusi mendukung adanya constructivism yang merupakan tahap pada pendekatan open ended juga memberikan pengaruh positif terhadap pencapaian kemampuan pemecahan masalah matematis siswa yang menggunakan model CORE dengan pendekatan open ended. Pada tahap constructivism siswa membentuk pengetahuan barunya sendiri yang berasal dari kegiatan diskusi pada model CORE. Hal ini sejalan dengan penelitian Satriani (2015) bahwa konstruktivisme merupakan suatu posisi filosofis yang memandang pengetahuan sebagai hasil dari pengalaman yang diperoleh dari kombinasi pengalaman pribadi seseorang dengan pengalaman yang dikonstruksi orang lain. Sehingga melalui kegiatan diskusi siswa harus mendapatkan pengetahuannya sendiri melalui interaksi dengan lingkungannya. Diskusi memberikan keleluasaan kepada siswa untuk mendapatkan pengetahuan baru yang berasal dari dirinya dan teman diskusinya yang kemudian diolah menghasilkan pemahamannya sendiri sehingga pembelajaran menjadi lebih bermakna. Belajar bermakna akan lebih diingat siswa dibandingkan dengan belajar menghafal. Diskusi memfasilitasi siswa untuk bertukar pengetahuan yang memungkinkan pembangunan pengetahuan baru dan menguatkan pengetahuan yang diyakini dalam menyelesaikan 
masalah sehingga siswa dapat memberikan solusi permasalahan sesuai dengan metode yang diyakini. Hal tersebut didukung oleh penelitian yang dilakukan oleh Agustianti (2018) bahwa proses diskusi didukung oleh proses mengakomodasi konsep yang telah dimiliki siswa dengan sesuatu hal yang baru yang diberikan oleh teman dan guru. Proses diskusi memberikan kesempatan kepada siswa untuk menggali materi secara mandiri sehingga dapat melatih untuk mengakomodasi pengetahuan yang dimiliki dengan pengetahuan yang baru melalui kegiatan bertanya, menyampaikan ide atau pendapat kepada guru maupun teman (Khafidhoh, 2014: 80). Selain itu, dalam pembelajaran CORE dengan pendekatan open ended siswa diarahkan melakukan kegiatan menyelesaikan berbagai jenis permasalahan untuk meningkatkan kemampuan siswa dalam menyelesaikan masalah yang dilaksanakan melalui tahap extending. Pembiasaan ini membuat siswa menjadi terlatih untuk memberikan solusi sebagai penyelesaian bermacam-macam jenis permasalahan. Hal ini sejalan dengan penelitian Khafidhoh (2014) bahwa tahap extending mendukung siswa untuk menyelesaikan masalah yang diberikan atau memberikan contoh permasalahan yang berkaitan dengan materi yang sedang dipelajari. Dan dalam penelitiannya tahap extending merupakan salah satu faktor yang paling memberikan pengaruh positif dengan rata-rata 4 terhadap kemampuan pemecahan masalah matematis.

Berdasarkan pengujian hipotesis yang telah dilakukan hasilnya menunjukkan bahwa peningkatan kemampuan pemecahan masalah matematis siswa kelas eksperimen yaitu siswa yang menggunakan model CORE dengan pendekatan open ended lebih baik daripada siswa kelas kontrol yaitu siswa yang menggunakan model saintifik.

Peningkatan kemampuan pemecahan masalah matematis siswa disebabkan siswa sering diberikan contohcontoh masalah dan meminta siswa untuk memberikan solusi permasalahan tersebut. Jenis soal yang diberikan adalah soal non rutin dalam penelitian ini juga merupakan soal open ended sehingga siswa terbiasa menyelesaikan dan memberikan solusi. Hal ini didukung oleh penelitian yang dilakukan oleh Murni (2013) bahwa pembiasaan pemberian soal non rutin meningkatkan kemampuan pemecahan masalah. Kemampuan pemecahan masalah merupakan kemampuan yang melibatkan kemampuan tingkat tinggi sehingga siswa dengan kemampuan pemecahan masalah yang baik akan terbiasa dalam menghadapi masalah dan dapat dengan mudah dalam melakukan proses penyelesaian masalah.

Menurut Kusumah (2010) pemecahan masalah sebagai suatu tujuan memuat tiga kemampuan yang ingin dicapai, yakni memodelkan masalah sehari-hari dengan memakai simbol dan notasi matematik, menerapkan strategi untuk menyelesaikan berbagai masalah (masalah sejenis ataupun masalah baru) di dalam atau di luar matematika serta menafsirkan hasil yang diperoleh secara bermakna dengan konteks masalah. Berikut dipaparkan cara penyelesaian masalah yang diberikan oleh siswa kelas eksperimen yaitu siswa yang mendapat- 
kan model CORE dengan pendekatan open ended pada soal kemampuan pemecahan masalah matematis.

Gambar 1 merupakan gambar soal kemampuan pemecahan masalah matematis untuk indikator 1 yaitu mengidentifikasi kecukupan data untuk menyelesaikan masalah. Soal tersebut meminta siswa untuk menentukan apakah uang yang dimiliki oleh Pak Hasan cukup atau tidak untuk membeli pohon yang akan ditanam pada sekeliling kebun. Hal tersebut dapat terjawab apabila siswa berhasil mengidentifikasi panjang dan lebar kebun tersebut.

Gambar 2 merupakan contoh jawaban yang diberikan oleh siswa kelas eksperimen untuk soal kemampuan pemecahan masalah matematis pada indikator 1 yaitu mengidentifikasi kecukupan data untuk menyelesaikan masalah. Berdasarkan pedoman penskoran yang digunakan jawaban siswa dikategorikan dapat mengidentifikasi kecukupan data dengan benar dan lengkap. Lebih jelasnya, siswa dapat mengidentifikasi panjang dan lebar kebun. Kemudian siswa memberikan kemungkinan-kemungkinan ukuran kebun sehingga diperoleh banyak pohon yang dibutuhkan melalui keliling kebun tersebut sehingga dapat ditentukan apakah uang yang dimiliki cukup untuk membeli pohon tersebut atau tidak. Selain itu, proses penyelesaian masalah menjadi baik karena di akhir penyelesaian masalah siswa memberikan kesimpulan dari perhitungan yang telah dilakukan dan menunjukkan jawahan yang benar.

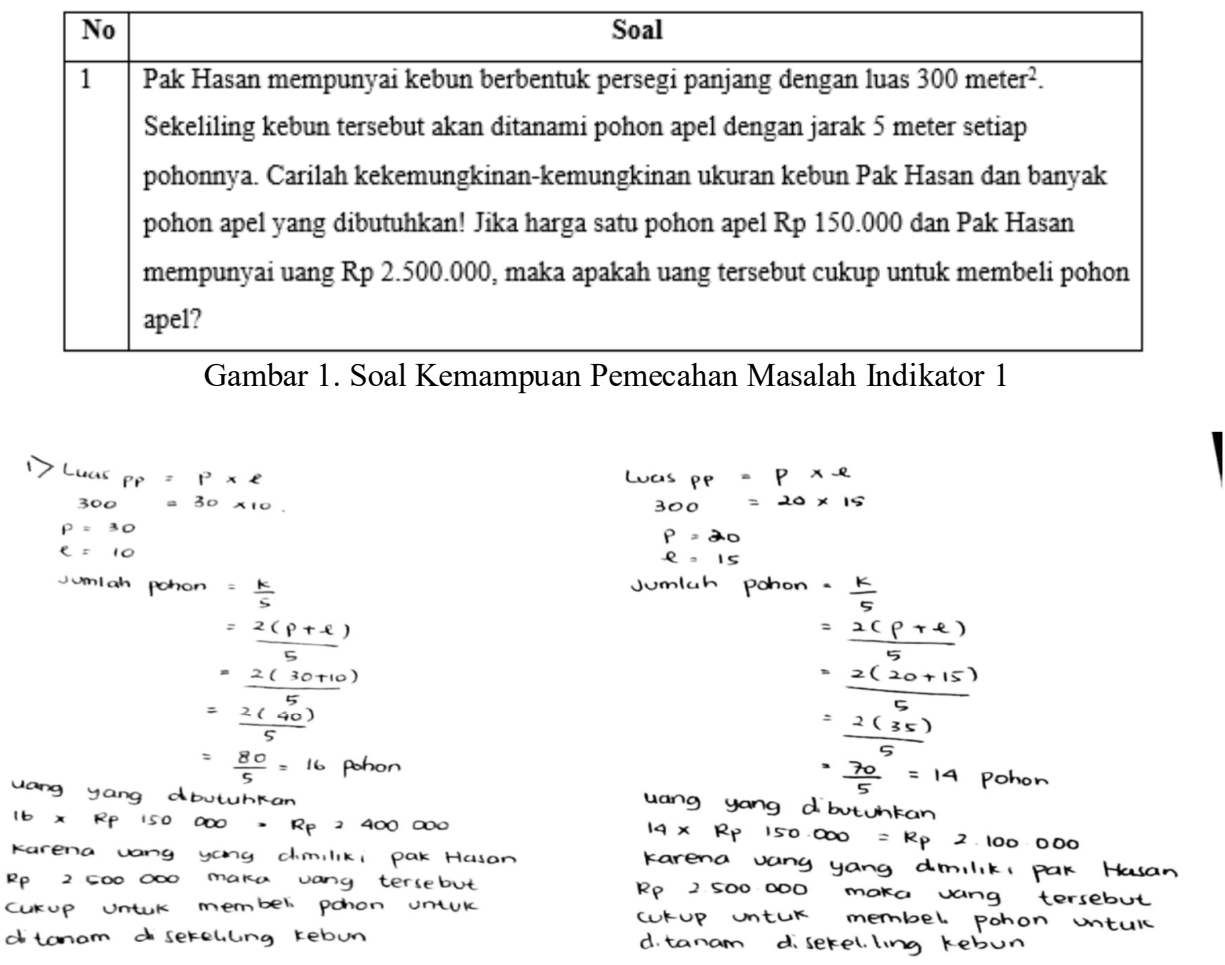

Gambar 2. Contoh Penyelesaian Masalah KPM Indikator 1 


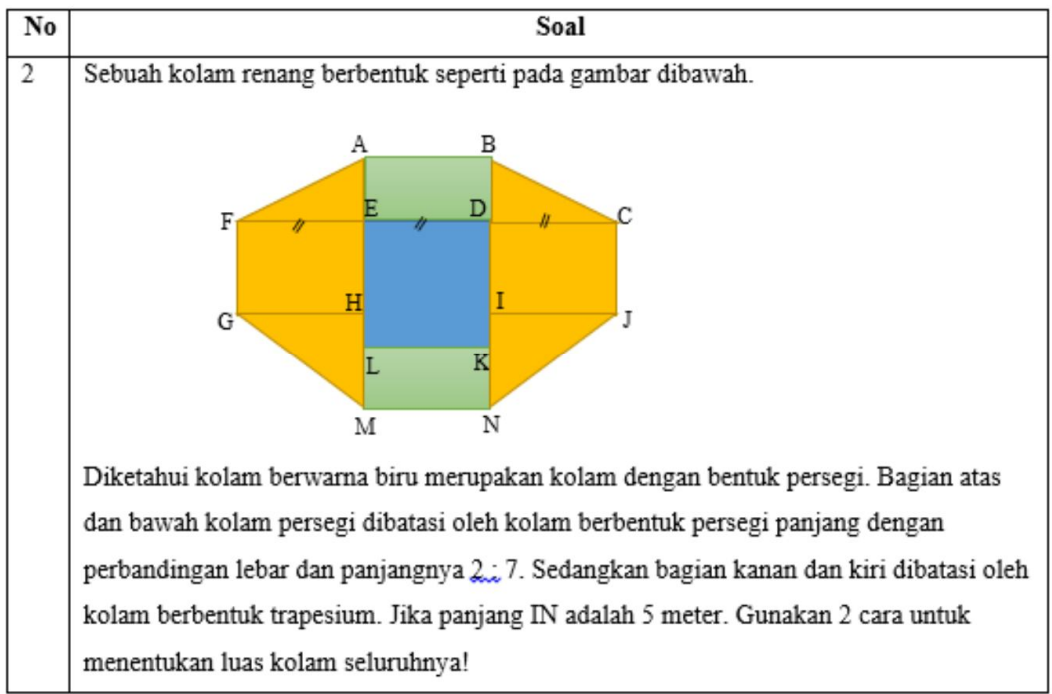

Gambar 3. Soal Kemampuan Pemecahan Masalah Indikator 2
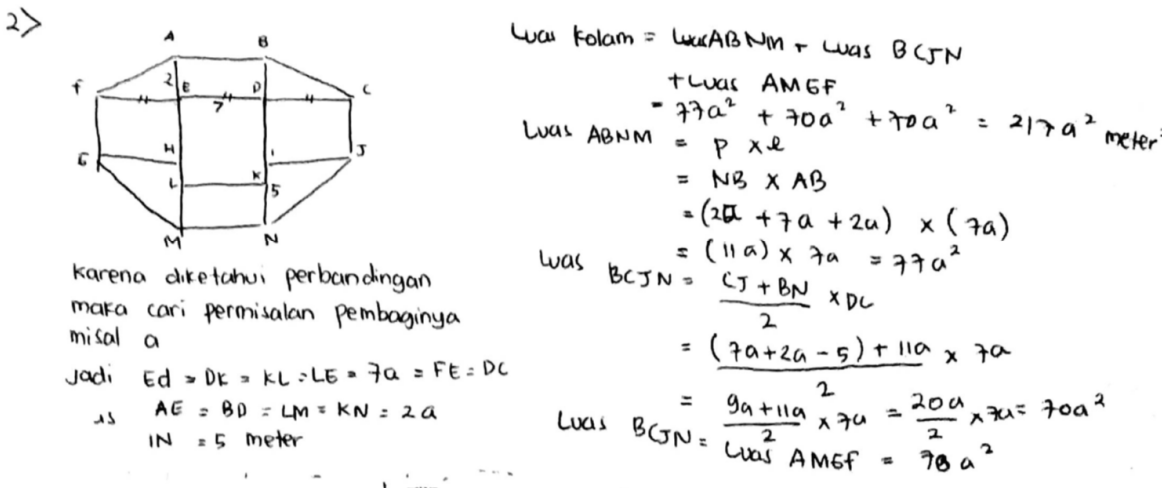

Gambar 4. Contoh Penyelesaian Masalah KPM Indikator 2

Gambar 3 merupakan gambar soal kemampuan pemecahan masalah matematis untuk indikator 2 yaitu menyusun model matematis. Dalam soal ini siswa diminta untuk menghitung luas kolam seluruhnya yang dapat dicari melalui jumlah luas beberapa bangun datar.

Gambar 4 merupakan contoh jawaban yang diberikan oleh siswa kelas eksperimen untuk soal kemampuan pemecahan masalah matematis pada indikator 2 yaitu menyusun model matematis sebagai penyelesaian masalah dan/atau yang akan digunakan untuk menyelesaikan masalah. Berdasarkan pedoman penskoran yang digunakan jawaban siswa dikategorikan dapat menuliskan rumus yang akan digunakan dalam menyelesaikan masalah dengan benar namun kurang lengkap. Lebih jelasnya, siswa kelas eksperimen dapat menentukan panjang sisi melalui perbandingan yang diberikan atau dapat menggunakan permisalan untuk mempermudah dalam perhitungan. Akan tetapi pada pertengahan proses perhitungan siswa kurang teliti sehingga terdapat kekeliruan. Soal ini berkaitan dengan soal operasi hitung bentuk aljabar yang telah diterima oleh siswa 


\begin{tabular}{|l|l|}
\hline No & \multicolumn{1}{|c|}{ Soal } \\
\hline 3 & $\begin{array}{l}\text { Sebuah karton berbentuk persegi dengan panjang sisi }(3 \mathrm{x}+2) \mathrm{cm} \text {, Setiap pojok karton } \\
\text { dipotong persegi dengan ukuran panjang sisi }(\mathrm{x}+4) \mathrm{cm} \text {. Gunakanlah 2 cara untuk } \\
\text { menentukan luas karton yang tersisa! }\end{array}$ \\
\hline
\end{tabular}

Gambar 5. Soal Kemampuan Pemecahan Masalah Indikator 3

sebelumnya. Berdasarkan penelitian yang dilakukan hal ini dipengaruhi karena siswa masih belum memahami perhitungan pada bentuk aljabar. Selain itu siswa eksperimen hanya memberikan satu alternatif solusi sebagai penyelesaian masalah sedangkan yang diminta oleh soal adalah menggunakan dua cara.

Gambar 5 merupakan gambar soal kemampuan pemecahan masalah matematis untuk indikator 3 yaitu menerapkan strategi untuk menyelesaikan masalah.

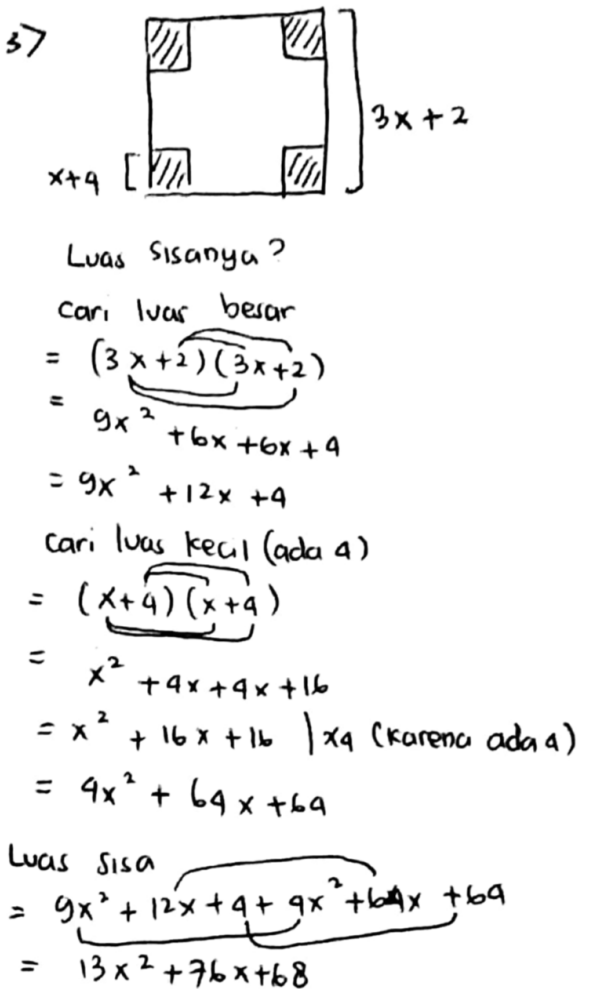

Gambar 6. Contoh Penyelesaian Masalah KPM Indikator 3
Gambar 6 merupakan contoh jawaban yang diberikan oleh siswa kelas eksperimen untuk soal kemampuan pemecahan masalah matematis pada indikator 3 yaitu menerapkan strategi yang akan digunakan dalam penyelesaian masalah. Berdasarkan pedoman penskoran yang digunakan jawaban siswa dikategorikan dapat menuliskan langkah penyelesaian dengan benar namun melakukan perhitungan kurang tepat atau lengkap. Lebih jelasnya, siswa kelas eksperimen dapat menentukan visualisasi bentuk yang diinginkan pada soal. Siswa menggambar bagian kertas yang akan dipotong dengan diarsir. Ini menunjukkan siswa mampu menentukan strategi penyelesaian masalah dengan cukup baik. Akan tetapi siswa kelas eksperimen melakukan kesalahan pada bagian perhitungan. Seharusnya luas sisa merupakan luas karton besar yang dikurangi luas empat karton kecil. Sedangkan siswa kelas eksperimen malah menjumlahkan semua bagian kertas karton. Selain itu siswa kelas eksperimen tidak memperhatikan satuan luas.

Gambar 7 merupakan gambar soal kemampuan pemecahan masalah matematis untuk indikator 4 yaitu menjelaskan atau menginterpretasi hasil pemecahan masalah.

Gambar 8 merupakan contoh jawaban yang diberikan oleh siswa kelas 


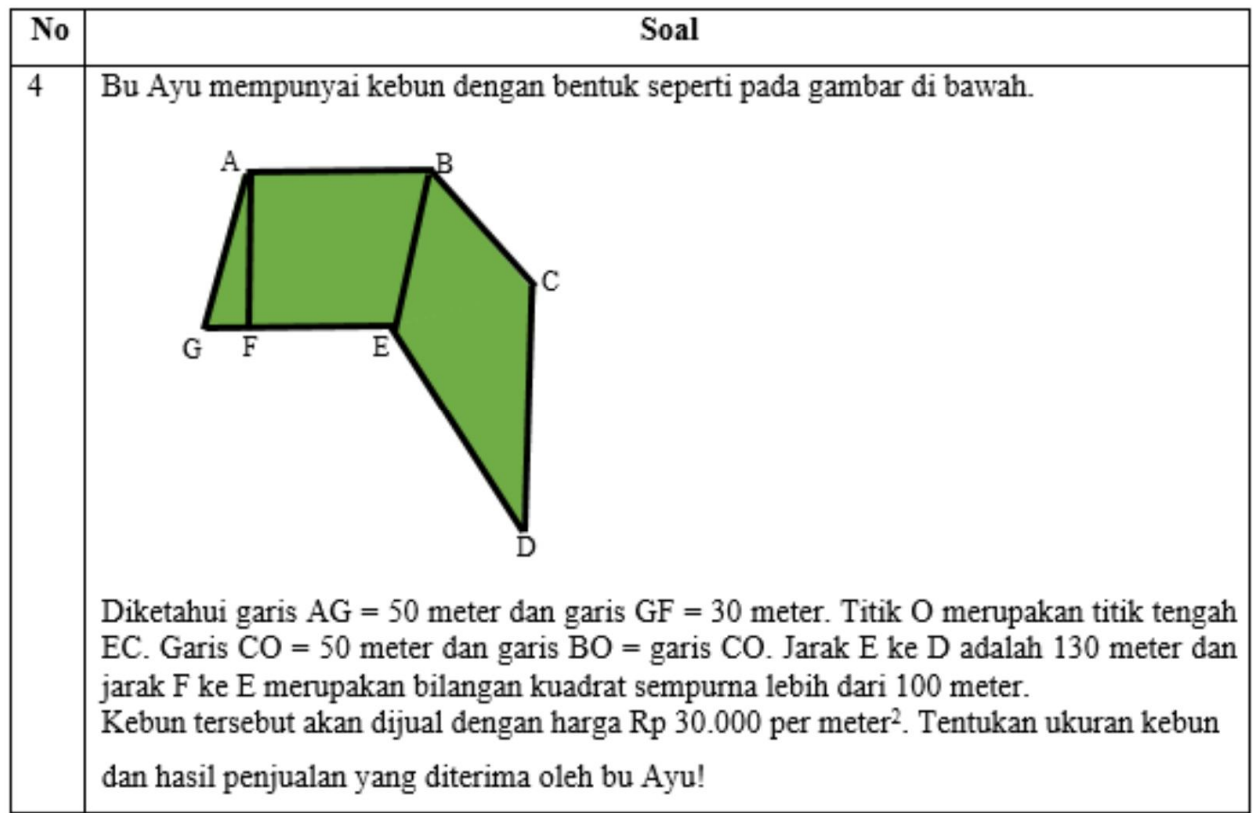

Gambar 7. Soal Kemampuan Pemecahan Masalah Indikator 4
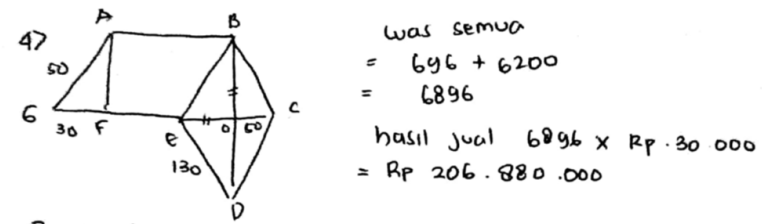

FE kuadrat sempurna $>100$
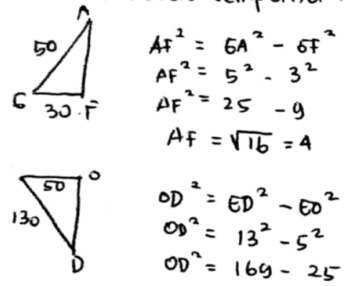

$$
\begin{aligned}
& O D^{2}=E D^{2}-E 0^{2} \\
& O D^{2}=13^{2}-5^{2} \\
& O D^{2}=169-25 \\
& O D=\sqrt{144}=12
\end{aligned}
$$

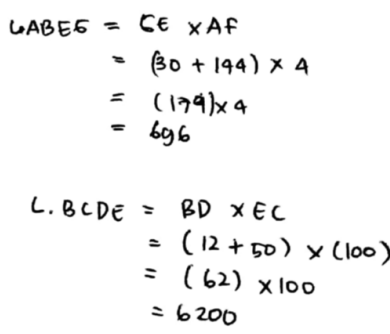

Gambar 8. Contoh Penyelesaian Masalah KPM Siswa Kelas Ekperimen Indikator 4

eksperimen untuk soal kemampuan pemecahan masalah matematis pada indikator 4 yaitu mejelaskan atau menginterpretasikan hasil pemecahan masalah. Berdasarkan pedoman penskoran yang digunakan jawaban siswa dikategorikan dapat menuliskan kesimpulan atau menjawab apa yang ditanyakan dengan benar namun kurang lengkap. Lebih jelasnya, siswa kelas eksperimen dapat menentukan panjang sisi lain menggunakan rumus phytagoras. Kemudian siswa bisa menentukan metode mencari luas bangun yang diberikan yaitu dengan menjumlahkan luas jajar genjang dan layang-layang. Namun, kesimpulan yang diberikan oleh siswa kurang lengkap. Aktivitas yang 
dilakukan siswa dengan model pembelajaran CORE memberikan kontribusi terhadap kemampuan pemecahan masalah siswa pada setiap indikator. Salah satu penyebabnya adalah karena siswa aktif membangun pengetahuannya sendiri sehingga pengetahuan menjadi bermakna bagi siswa. Hal ini diungkap oleh Hariyanto (2016) bahwa model pembelajaran CORE merupakan model pembelajaran altrenatif yang dapat digunakan untuk mengaktifkan siswa dalam membangun pengetahuannya sendiri. Diungkap pula oleh Muizaddin (2016) dengan model pembelajaran CORE, hasil pembelajaran yang meliputi hasil belajar kognitif berada pada kategori sangat tinggi atau $100 \%$ siswa mendapatkan hasil diatas KKM yang disyaratkan. Lebih spesifik disimpullkan bahwa model pembelajaran CORE memberikan pengaruh terhadap kemampuan pemecahan masalah matematika. Untuk itu model pembelajaran CORE secara signifikan dapat digunakan untuk meningkatkan kemampuan pemecahan masalah matematika siswa (Satriani, 2015).

\section{SIMPULAN}

Berdasarkan analisis data hasil penelitian dan pembahasan pada seluruh tahapan penelitian diperoleh kesimpulan bahwa pencapaian dan peningkatan kemampuan pemecahan masalah matematis siswa yang menggunakan model pembelajaran CORE dengan pendekatan open ended lebih baik daripada pencapaian dan peningkatan kemampuan pemecahan masalah matematis siswa dengan menggunakan pembelajaran ekspositori.

\section{DAFTAR PUSTAKA}

Agustiani, E. (2018). Penggunaan Model Pembelajaran Problem Based Learning untuk Meningkatkan Hasil Belajar Siswa pada Subtema Keberagaman Budaya Bangsaku. Fakultas Keguruan dan Ilmu Pendidikan Universitas Pasundan.

Arifah, Y.N. dkk. (2016). Keefektifan Model Pembelajaran CORE Berbantuan Strategi Studi Kasus terhadap Kemampuan Berpikir Kreatif Siswa SMP. Jurnal Penelitian Pendidikan, 2(1): 124130.

Hariyano. (2016). Penerapan Model CORE Dalam Pembelajaran Matematika Untuk Meningkatkan Kemampuan Komunikasi Matematik Siswa. Jurnal Gammath. 1(2). 33-40.

Husniah, G. N., Maulana, M, dkk. (2017). Pengaruh Pendekatan Open-Ended Terhadao Kemampuan Pemecahan Masalah Matematis Dan Motivasi Belajar. Jurnal Penelitian Pendidikan. 1: 841-850.

Jacob, C. (2005). Pengembangan Model CORE dalam Pembelajaran Logika dengan Pendekatan Reciprocal Teaching bagi Siswa SMA Negeri 9 Bandung dan SMA Negeri 1 Lembang. Laporan Piloting FMIPA UPI. Bandung: Tidak diterbitkan.

Jihad, A. \& Haris, A. (2012). Evaluasi Pembelajaran. Yogyakarta: Multi Presindo.

Khafidhoh, S. (2014). Penerapan Model Connecting, Organizing, Reflecting dan Extending (CORE) untuk Meningkatkan Kemampuan Pemecahan Masalah Matematika Siswa pada Materi Bangun Ruang 
Sisi Lengkung Kelas IX MTs Negeri Mojokerto. Fakultas Ilmu Tarbiyah dan Keguruan Universitas Islam Negeri Sunan Ampel Surabaya.

Kusumah, Y. (2010). Dampak Pendidikan Matematika Realistik terhadap Peningkatan Kemampuan Pemecahan Masalah Siswa. Jurnal IndoMS. J.M.E. Vol 1 No 1 Juli 2010.pp 41-51.

Lestari, K. E. \& Yudhanegara, M. R. (2017). Penelitian Pendidikan Matematika. Bandung: PT Refika Aditama.

Maftukhah, N. A., Nurhalim, K. dan Isnarto. (2016). Kemampuan Berpikir Kreatif dalam Pembelajaran Connecting Organizing Reflecting Extending Ditinjau dari Kecerdasan Emosional. Jurnal Penelitian Pendidikan. 6(3): 267-276.

Mendiknas. (2006). Tujuan Pembelajaran Matematika. Jakarta: Departemen Pendidikan Nasional.

Muizzaddin. (2016). Model pembelajaran CORE sebagai sarana dalam meningkatan hasil belajar siswa. Jurnal Pendidikan Manajemen Perkantoran. 1(1): 224-232

Murni. A. (2013). Peningkatan Kemampuan Pemecahan Masalah dan Representasi Matematis Siswa SMP Melalui Pembelajaran Metakognitif Berbasis Soft Skills. Skripsi: Universitas Pendidikan Indonesia.

NCTM. (2000). Principle and Standards for School Mathematics. Reston VA: NCTM.

Saputra, A.D. (2016). Penerapan Model Pembelajaran Connecting, Organizing, Reflecting dan Extending (CORE) dengan
Pendekatan Scientific terhadap Peningkatan Kemampuan Pemecahan Masalah Matematis pada Siswa SMP. Skripsi : tidak diterbitkan.

Satriani, G. A. N. D., Dantes, N., dkk. (2015). Pengaruh Penerapan Model Core terhadap Kemampuan Pemecahan Masalah Matematika dengan Kovariabel Penalaran Matematis pada Siswa Kelas III Gugus Raden Ajeng Kartini Kecamatan Denpasar Barat. Jurnal Program Pascasarjana Universitas Pendidikan Ganesha . 5(1): 1-10.

Shoimin, A. (2014). 68 Model Pembelajaran Inovatif dalam Kurikulum 2013. Yogyakarta: Ar Ruzz Media.

Sudjana, N. (2010). Penilaian Hasil Proses Belajar Mengajar. Bandung: PT Remaja Rosdakarya.

Sugiyono. (2012). Metode Penelitian Kuantitatif, Kualitatif, dan R\&D. Bandung: Alfabeta.

Suryana, D. (2016). Pendidikan Anak Usia Dini: Stimulasi \& Aspek Perkembangan Anak. Jakarta: Prenada Media.

Utami, R. W. \& Wutsqa, D. U. (2017). Analisis Kemampuan Pemecahan Masalah Matematika dan Self Efficacy Siswa SMP Negeri di Kabupaten Ciamis. Jurnal Penelitian Pendidikan. 4(2): 166-175.

Vitasari, N \& Trisniawati. (2017). Peningkatan Kemampuan Pemecahan Masalah Matematis Mahasiswa PGSD Universitas Sarjanawiyata Tamansiswa Melalui Problem Posing. 1.78-86.

Wardhani, S. (2010). Pembelajaran Kemampuan Pemecahan Masalah Matematika di SD. Yogyakarta: PPPPT. 
